Review

\title{
Environmentally-Benign Dimethyl Carbonate-Mediated Production of Chemicals and Biofuels from Renewable Bio-Oil
}

\author{
Keon Hee Kim and Eun Yeol Lee* \\ Department of Chemical Engineering, Kyung Hee University, Gyeonggi-do 17104, Korea; geoni@khu.ac.kr \\ * Correspondence: eunylee@khu.ac.kr; Tel.: +82-31-201-3839
}

Received: 27 September 2017; Accepted: 5 November 2017; Published: 7 November 2017

\begin{abstract}
Due to the increasing emission of carbon dioxide $\left(\mathrm{CO}_{2}\right)$, the development of fuels and chemicals based on renewable resources has attracted much attention. Bio-oil, as a carbon rich material, has been considered as a feedstock for biodiesel production. In conventional methanol-mediated transesterification of bio-oil for biodiesel production, significant amounts of glycerol are being generated as a byproduct. In order to overcome these issues, dimethyl carbonate (DMC) has been recently used as an alternative acyl acceptor to avoid the generation of glycerol. DMC is an environmentally-benign chemical reagent and reactive solvent due to safety, health, and environmental benefits. Moreover, $\mathrm{DMC}$ can be produced from $\mathrm{CO}_{2}$. Co-production of biodiesel and chemicals such as glycerol carbonate is possible as the concept of zero-waste utilization of bio-oil. Value-added chemicals can be synthesized using DMC as a reagent. This paper provides a review on the physical and chemical properties of DMC as a solvent, as well as the production methods for DMC. DMC-mediated production of various chemicals and fuels in both chemical and enzymatic processes are discussed together with their pros and cons.
\end{abstract}

Keywords: biodiesel; bio-oil; dimethyl carbonate; glycerol carbonate

\section{Introduction}

The intensive consumption of petroleum-derived fuels and chemicals causes environmental and political concerns. In order to solve these issues, the development of renewable fuel and chemical production from biomass has increased. Bio-feedstocks are renewable, sustainable, biodegradable, environmentally friendly, and carbon neutral over the whole life cycle [1]. Bio-oils can be obtained from various biomasses, such as vegetable, animal, and microalgae, and are carbon-rich materials consisting of glycerol and three fatty acids with chain lengths between C8 and C20 [2]. Thus, they are considered as a practical alternative to petroleum resources for biofuel and chemical production.

The refined bio-oil (triglyceride) is mainly used as an alternative feedstock for biodiesel production. Biodiesel, defined as fatty acid alky esters (FAAEs), is produced by the transesterification of the refined bio-oil with alcohols in the presence of a catalyst. Various alcohols, including methanol, ethanol, propanol, butanol, and amyl alcohol are used as acyl acceptors in the transesterification reaction [3]. Among all of the alcohols, methanol and ethanol are most employed for conventional biodiesel production. Methanol is especially preferred on the industrial level because of its economic advantages [3,4]. However, methanol is a hazardous material that is handled carefully due to its toxicological and ecotoxicological properties [3,5]. The utilization of green solvents such as ethanol, iso-propanol, and n-butanol has been studied as an alternative to overcoming these issues of methanol [6-8]. However, alcohol-mediated transesterification processes generate approximately $10 \mathrm{wt}$ $\%$ crude glycerol (Figure 1) [9]. With a growing biodiesel industry, a large surplus of glycerol has been produced [10,11]. For example, over 1400 kilo tons of glycerol were created from biodiesel production 
in 2013 [12]. Glycerol, as a low-cost feedstock, can be used for chemical, pharmaceutical, and cosmetic industries, but the cost of separation and purification of crude glycerol is relatively high [10,13-15].

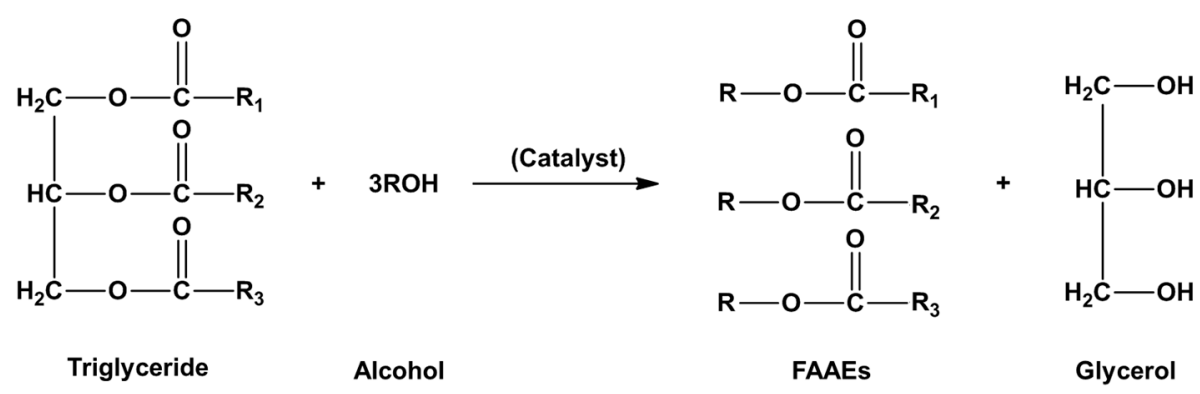

Figure 1. Reaction pathway of fatty acid alkyl ester (FAAE) synthesis from bio-oil and alcohol.

To overcome the issues of alcohol-mediated transesterification, an alternative novel acyl acceptor, dimethyl carbonate (DMC), has been employed for glycerol-free biodiesel synthesis. DMC is a green chemical reagent or reactive solvent due to its non-toxic impact on health and the environment [16]. Additionally, DMC is utilized as a versatile raw material for pharmaceuticals and as a solvent for various industrial applications $[17,18]$. Moreover, $\mathrm{DMC}$ synthesis from undesired $\mathrm{CO}_{2}$ is a promising option for green-house gas mitigation [19].

In this paper, we review the physico-chemical properties (Section 2) and production methods (Section 3) of DMC, and chemical and biotechnical processes for DMC-based production of biodiesel and chemicals (Sub-Sections 4.1 and 4.2 in Section 4). The simultaneous production of biodiesel and value-added chemicals using renewable bio-oil in DMC is also discussed in terms of zero-waste utilization and $\mathrm{CO}_{2}$-sequestration (Sub-Section 4.3 in Section 4). This review paper deals with various research articles, review papers, and some patents.

\section{Physico-Chemical Properties of DMC}

DMC is a flammable (flash point $21.7^{\circ} \mathrm{C}$ ), colorless liquid with a melting point of $4.6^{\circ} \mathrm{C}$ and boiling point of $90.3^{\circ} \mathrm{C}$, and a density of $1.069 \mathrm{~g} / \mathrm{cm}^{3}$ [18]. DMC, a nonpolar aprotic solvent, is slightly soluble in water $(139 \mathrm{~g} / \mathrm{L})$ [20] and miscible with alcohol, ester, ether, and ketone [21]. The chemical reactivity of DMC is versatile. DMC has two carbon centers including carbonyl and methyl groups, with which a nucleophile may react. Thus, DMC is employed as a methylating or carboxylating agent $[20,21]$.

The most important properties of DMC are low toxicity and high biodegradability $(>90 \%$ within 28 days) $[18,21]$. The oral acute toxicity $\left(\mathrm{LD}_{50}\right)$ of $\mathrm{DMC}$ for rats is $13.8 \mathrm{~g} / \mathrm{kg}$, which indicates that it is a non-toxic compound. In addition, DMC has a negligible toxic effect by inhalation $[17,22]$. Therefore, DMC can be safely handled compared to toxic methyl halides, dimethyl sulfate (DMS), and phosgene $[18,20,22]$. The toxicological and ecotoxicological properties of DMC, DMS, and phosgene are summarized in Table 1.

Table 1. Summary of toxicological and ecotoxicological properties of dimethyl carbonate (DMC), dimethyl sulfate (DMS), and phosgene (modified from $[17,22])$.

\begin{tabular}{cccc}
\hline Properties & DMC & DMS & Phosgene \\
\hline Oral acute toxicity (rats) & $\mathrm{LD}_{50} 13.8 \mathrm{~g} / \mathrm{kg}$ & $\mathrm{LD}_{50} 0.44 \mathrm{~g} / \mathrm{kg}$ & - \\
Acute toxicity per contact (cavy) & $\mathrm{LD}_{50}>2.5 \mathrm{~g} / \mathrm{kg}$ & - & - \\
Acute toxicity per inhalation (rats) & $\mathrm{LD}_{50} 140 \mathrm{mg} / \mathrm{L} ;(4 \mathrm{~h})$ & $\mathrm{LD}_{50} 1.5 \mathrm{mg} / \mathrm{L} ;(4 \mathrm{~h})$ & $\mathrm{LD} 50$ 0.016 $\mathrm{mg} / \mathrm{L} ;(75 \mathrm{~min})$ \\
Mutagenic properties & None & Mutagenic & - \\
Irritating properties (rabbits, eyes, skin) & None & - & Corrosive \\
Biodegradability & $>90 \%(28$ days $)$ & Rapid hydrolysis & Rapid hydrolysis \\
\hline
\end{tabular}




\section{DMC Production Process}

DMC has been produced by conventional methods or $\mathrm{CO}_{2}$-based methods (Figure 2). The conventional methods involve two methods: the non-phosgene route and the phosgene process [23]. The methods utilizing $\mathrm{CO}_{2}$ include the direct DMC synthesis with methanol and indirect DMC synthesis with intermediates including $\mathrm{CO}_{2}$-derived urea, propylene carbonate, and ethylene carbonate.

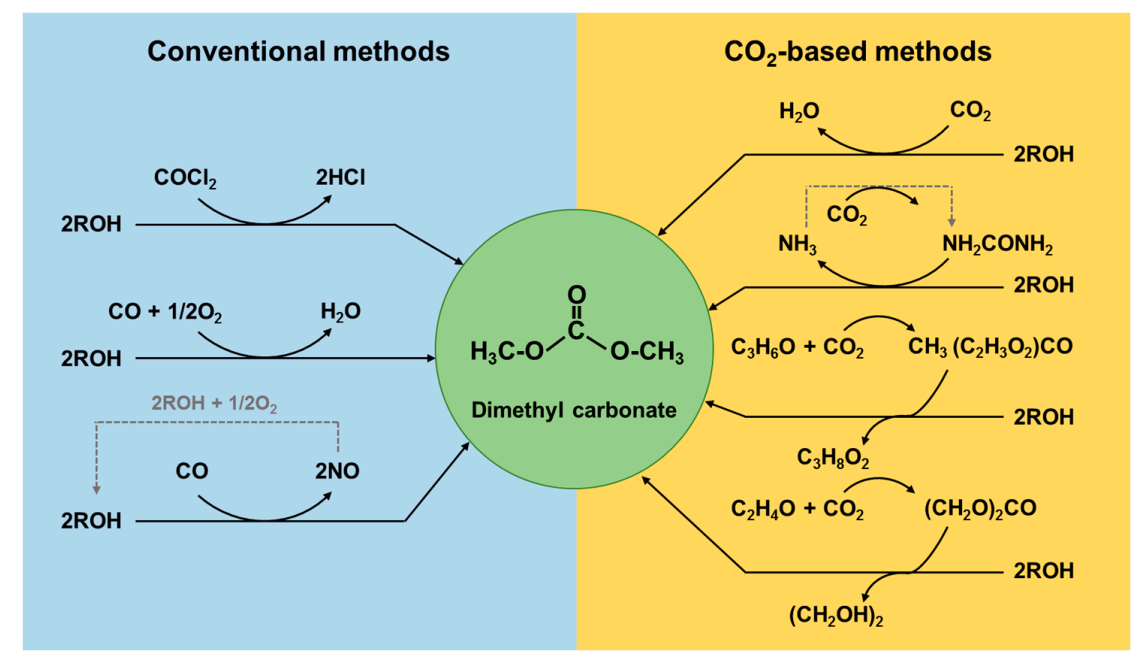

Figure 2. Synthesis routes of dimethyl carbonate modified from [17].

\subsection{Conventional Process of DMC Production}

Until the 1980s, DMC was produced by the phosgene process. Despite a high yield, the phosgene process is no longer used due to high toxicity of phosgene and the equipment corrosion by the phosgene and $\mathrm{HCl}$ generated in the process $[19,22]$. Currently, DMC is produced by oxidative partial carbonylation, using methanol, carbon monoxide, and oxygen in the liquid or vapor phase [24,25]. Oxidative carbonylation of methanol is thermodynamically favorable and the process is operated at moderate conditions $[17,26]$. Chlorine-containing catalysts are usually employed in the processes, and chlorine is related to the activity of the catalyst [27]. The liquid phase method has a high space-time yield of DMC [17]. However, it has issues of a low production rate, equipment corrosion, difficult separation of products from catalysts, and rapid deactivation of catalysts by the accumulation of water $[25,26]$. In order to overcome the issues, the vapor phase method has been proposed. The vapor phase method can readily remove water that has a negative effect on catalysts. As an alternative phosgene-free route, carbonylation of methyl nitrites over Pd-based catalysts was also developed by Ube Industries, Ltd. [19]. In this method, alkyl nitrites were employed as an oxidizing agent, and water was not accumulated during the synthesis of DMC, which eliminated the negative effects of water on catalysts. Thus, anhydrous condition resulted in high catalytic activity and selectivity for a long reaction time [16]. However, phosgene-free routes still use toxic and corrosive compounds including nitrogen oxide, methyl nitrite, and carbon monoxide, and thus explosion might occur in methanol carbonylation method $[17,19]$.

\subsection{DMC Production from Carbon Dioxide}

$\mathrm{CO}_{2}$ from fossil fuels is the most abundant waste gas leading to the greenhouse effect. The method of converting $\mathrm{CO}_{2}$ into value-added chemicals has recently attracted much interest [28]. The production of DMC using $\mathrm{CO}_{2}$ as $\mathrm{C} 1$ feedstock has been considered as a green chemistry route compared to the conventional process. Processes for $\mathrm{DMC}$ production from $\mathrm{CO}_{2}$ possess several routes such as the direct reaction with methanol and indirect reaction with intermediate compounds (urea, ethylene carbonate, propylene carbonate) $[18,19]$. 
The direct synthesis of DMC from $\mathrm{CO}_{2}$ and methanol is an environmentally-benign method for $\mathrm{CO}_{2}$ utilization, free from the risk of explosion in oxidative carbonylation. In general, organometallic complexes and inorganic bases have been used in the direct synthesis of $\mathrm{DMC}$ from $\mathrm{CO}_{2}$ and methanol at near supercritical conditions [29-31]. Jiang et al. [31] analyzed the effect of $\mathrm{H}_{3} \mathrm{PW}_{12} \mathrm{O}_{40} / \mathrm{ZrO}_{2}$ as a catalyst in the direct synthesis of $\mathrm{DMC}$ from $\mathrm{CO}_{2}$ and methanol. $\mathrm{H}_{3} \mathrm{PW}_{12} \mathrm{O}_{40} / \mathrm{ZrO}_{2}$ possessed a high catalytic activity for DMC production when compared to a pure zirconia catalyst because $\mathrm{H}_{3} \mathrm{PW}_{12} \mathrm{O}_{40} / \mathrm{ZrO}_{2}$ has not only Lewis acid sites, but also Brønsted acid sites. Brønsted acid sites in the $\mathrm{H}_{3} \mathrm{PW}_{12} \mathrm{O}_{40} / \mathrm{ZrO}_{2}$ were more effective for methanol activation than Lewis acid sites. However, this method still remains at the laboratory-scale because the DMC conversion was very low due to the reaction equilibrium limitation and kinetic inertness of $\mathrm{CO}_{2}$ [16].

In indirect routes, urea, ethylene carbonate, and propylene carbonate are synthesized from $\mathrm{CO}_{2}$ with ammonia, ethylene oxide, and propylene oxide, respectively. DMC was produced through subsequent transesterification of these compounds with methanol [19]. The production of DMC by alcoholysis of urea was performed using organic tin, polyphosphoric acid (PPA), metal oxide, and zinc compounds [32]. In propylene carbonate and ethylene carbonate routes for DMC production, valuable chemicals such as propylene glycol and ethylene glycol were obtained as byproducts [19]. Alkali metal compounds, silica-supported ionic liquids, and alkali-treated zeolite were effective in transesterification [32]. Kongpanna et al. [19] reported the techno-economic analysis of three processes for DMC synthesis. The $\mathrm{CO}_{2}$ direct synthesis and propylene carbonate route were less competitive than the other $\mathrm{CO}_{2}$ utilizing routes because of high positive value of Gibbs free energy and low DMC yield [19]. The ethylene carbonate route is a promising method for DMC preparation in terms of atom efficiency, total energy consumption ( $11.4 \%$ improvement), and net $\mathrm{CO}_{2}$ emission (13.4\% improvement) [19].

\section{DMC-Mediated Production of Fuels and Chemicals}

DMC has been widely used in various chemical industry as an attractive green chemical [32]. The DMC-mediated processes for the production of fuel and chemical production were reviewed according to the chemical and enzymatic catalysts.

\subsection{DMC-Mediated Process for Biodiesel Production}

In biodiesel production using transesterification with bio-oil, methanol is commonly used as an acyl acceptor. However, there are some problems such as lower miscibility with oil, denaturation of enzymes, and the overproduction of glycerol [10,33]. In particular, the glycerol byproduct needs to be separated because it cannot be directly added to fuels due to its higher viscosity, instability at high temperature, and lower solubility in hydrocarbons [5]. The separation process would increase the biodiesel production cost. Therefore, using DMC as a novel acyl acceptor has been recently proposed for glycerol-free biodiesel production. DMC is known to be a green reagent and prevents co-production of glycerol [15]. In addition, glycerol derivatives, such as glycerol carbonate and glycerol dicarbonate, are obtained as value-added byproducts through DMC-mediated transesterification [15]. Glycerol carbonate and glycerol dicarbonate can be used as additives or chemical intermediates, thus can mitigate the glycerol surplus from conventional biodiesel process [15]. Two possible reaction pathways in DMC-mediated transesterification have been proposed (Figure 3). Zhang et al. [34] suggested a plausible reaction route in which fatty acid glycerol carbonate esters (FAGCs) as intermediates react with DMC to produce glycerol dicarbonate and fatty acid methyl esters (FAME). Then, glycerol dicarbonate is converted into glycerol carbonate via hydrolysis. Another possible reaction route is that glycerol carbonate is synthesized from the glycerol backbone [35]. Additionally, the remaining non-reacted DMC can be employed as a fuel additive for diesel engines [36]. The DMC-mediated process for biodiesel synthesis is an irreversible reaction because it produces $\mathrm{CO}_{2}$ in the final step, thus the yields of DMC are high [37]. The $\mathrm{CO}_{2}$ generated via DMC-based transesterification can be utilized again for DMC synthesis. 


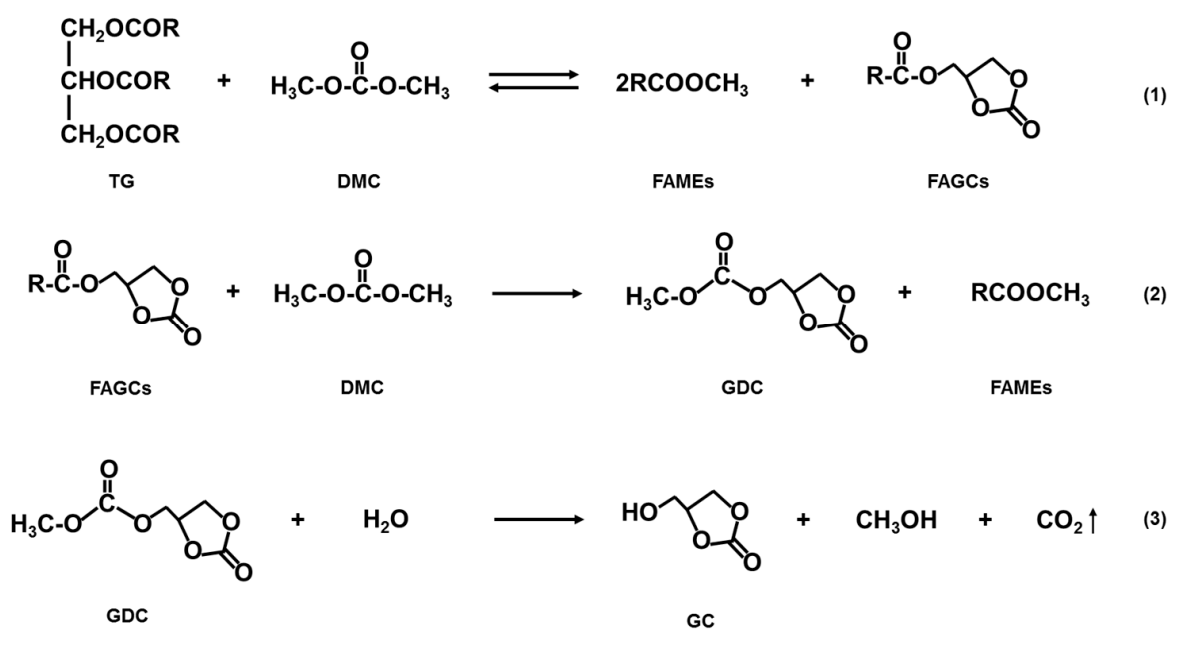

(a)

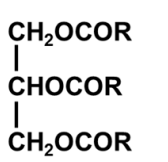

TG<smiles>OCC(O)CO</smiles>

Glycerol

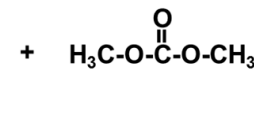

DMC
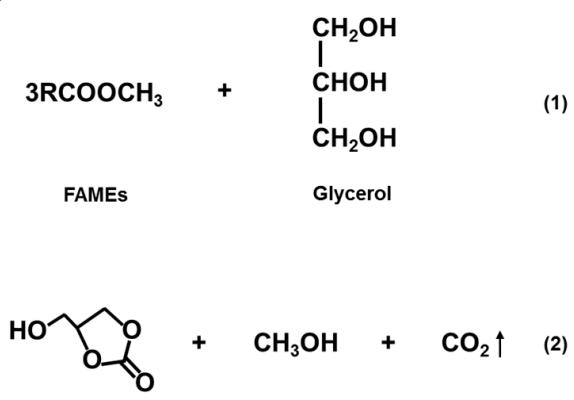

GC

(b)

Figure 3. Two possible reaction pathways for DMC-mediated transesterification: (a) one was suggested by Zhang et al. [34], (b) while the other was suggested by Min et al. [35]. TG, triglyceride; DMC, dimethyl carbonate; FAMEs, fatty acid methyl esters; FAGCs, fatty acid glycerol carbonate esters; GDC, glycerol dicarbonate; GC, glycerol carbonate.

\subsubsection{Chemical Process for DMC-Based Biodiesel Production}

The transesterification reaction between bio-oils and DMC produces FAMEs and value-added glycerol derivatives such as glycerol carbonate and glycerol dicarbonate. Basic catalysts like $\mathrm{KOH}$, sodium methoxide, sodium hydride, and some amines are most widely used for DMC-based transesterification [15,38-43]. Table 2 shows the use of alkaline catalysts for DMC-based biodiesel production. Panchal et al. [41] investigated the effect of different acid and base catalysts $\left(\mathrm{HCl}, \mathrm{H}_{2} \mathrm{SO}_{4}\right.$, $\mathrm{KOH}$, and $\mathrm{NaOH}$ ) for DMC-based biodiesel production. The maximum yield of FAMEs was achieved with the $\mathrm{KOH}$ catalyst. In an alkaline condition, a methoxide anion generated from DMC has a high catalytic activity in the transesterification reaction, as it is strongly basic [34,43]. The nucleophilic attack of the methoxide anion at the carbonyl carbon in triglyceride generates a tetrahedral intermediate, and then results in formation of one mole of FAME. The use of sodium methoxide as an alkali catalyst allows for a high yield of FAMEs under mild conditions in the transesterification reaction. Kai et al. [42] achieved a maximum conversion of $96 \%$ at $65{ }^{\circ} \mathrm{C}$ for $2 \mathrm{~h}$ with $2.0 \mathrm{wt} \%$ sodium methoxide catalyst and a 3:1 molar ratio of DMC and oil. Triazabicylodecene (TBD), as a nitrogen-containing catalyst, is a non-ionic organic base catalyst and has higher catalytic activity than other nitrogen based catalysts in the transesterification reaction [38,40]. Moreover, unrefined acidic oil (free fatty acid; FFA) can be used in the presence of TBD since the complex of TBD and FFA is soluble in the reaction solution, and thus there is no formation of soap or emulsions [44]. However, these processes generate alkaline waste water in their production plant [45]. 
Table 2. Summary of studies using chemical catalysts during DMC-mediated transesterification.

\begin{tabular}{ccccccc}
\hline Feedstock & Catalyst & $\begin{array}{c}\text { Catalyst } \\
\text { Amount (\%) }\end{array}$ & $\begin{array}{c}\text { Molar Ratio } \\
\text { (Oil:DMC) }\end{array}$ & $\begin{array}{c}\text { Reaction } \\
\text { Conditions }\end{array}$ & Yield (\%) & Reference \\
\hline Soybean oil & $\mathrm{KOCH}_{3}$ & 6.5 & $1: 9$ & $200{ }^{\circ} \mathrm{C}, 10 \mathrm{bar}, 1 \mathrm{~h}$ & 95.8 & {$[5]$} \\
Canola oil & $\mathrm{NaOCH}_{3}$ & 2 & $1: 3$ & $65^{\circ} \mathrm{C}, 2 \mathrm{~h}$ & $>96.0$ & {$[42]$} \\
Palm oil & $\mathrm{KOH}$ & 8.5 & $1: 9$ & $65-75^{\circ} \mathrm{C}, 8 \mathrm{~h}$ & 96.2 & {$[34]$} \\
Pongamia pinnata seed oil & $\mathrm{KOH}$ & 4 & $1: 3(w / w)$ & $90^{\circ} \mathrm{C}, 6 \mathrm{~h}$ & 96.0 & {$[41]$} \\
Karanja oil & $\mathrm{KOH}$ & 9 & $1: 10$ & $80^{\circ} \mathrm{C}, 8 \mathrm{~h}$ & $>96.0$ & {$[43]$} \\
Soybean oil & $\mathrm{TBD}^{\mathrm{a}}$ & 5 & $1: 3$ & $90^{\circ} \mathrm{C}, 5 \mathrm{~h}$ & $>99.5$ & {$[38]$} \\
Canola oil & $\mathrm{TBD}^{\mathrm{a}}$ & 1.5 & $1: 6$ & $60^{\circ} \mathrm{C}, 2 \mathrm{~h}$ & 98.0 & {$[39]$} \\
Canola oil & $\mathrm{TBD}^{\mathrm{a}}$ & 2.5 & $1: 3$ & $60^{\circ} \mathrm{C}, 1.013 \mathrm{bar}, 6 \mathrm{~h}$ & 99.45 & {$[40]$} \\
\hline \multicolumn{7}{c}{ a Triazabicylodecene. }
\end{tabular}

\subsubsection{Enzymatic Process for DMC-Based Biodiesel Production}

In order to overcome the drawbacks of chemical catalysis, enzymatic transesterification has been recently studied [46-52]. The enzymatic transesterification reactions using DMC as an acyl acceptor for biodiesel production are compared in Table 3. The enzymatic process has relatively easy separation, which could lower downstream separation cost [53]. Furthermore, the enzymatic process has the advantages of being environmental friendly and consuming less energy than a chemical process because it is performed under mild conditions [52,54]. Immobilization of enzymes on a suitable support allows reuse. One of the drawbacks of immobilized enzymes in the transesterification reaction is deactivation by short-chain alcohols and glycerol [52]. Enzyme deactivation can be prevented by employing DMC as an acyl acceptor [54]. In general, Novozyme 435 prepared from Candida antarctica lipase has been widely used as a biocatalyst for DMC-based biodiesel production. Go et al. [55] found that Novozyme 435 is more suitable for DMC-based biodiesel production than other reported lipases due to its non-specific nature.

Most of the studies on enzymatic transesterification using DMC utilize edible vegetable oils as renewable feedstock $[35,48,55]$. Edible oils, such as soybean oil, corn oil, and sunflower oil, cause the moral issue of using food resources for fuel production [56]. Recently, non-edible bio-oils, such as waste cooking oil and microalgae oil, have been explored as attractive options. Waste cooking oil was converted to biodiesel through DMC-mediated transesterification using Novozyme 435 in a solvent-free system [49]. Waste cooking oil can reduce feedstock cost for biodiesel production. With respect to microalgae, they have higher $\mathrm{CO}_{2}$ fixation rates and growth rates than terrestrial plants. Additional advantage is that some microalgae can accumulate abundant amounts of oil $(50-80 \%$ of dry biomass) [52,57]. Lee et al. [50] and Jo et al. [51] reported that lipase-catalyzed transesterification for DMC-based biodiesel production was performed using microalgae, Chlorella sp. KR-1, and the maximum yields were $75.5 \%$ and $90.5 \%$, respectively. The optimum temperature was in the range of 40 and $70{ }^{\circ} \mathrm{C}$ because the maximum allowable temperature for lipase was $70^{\circ} \mathrm{C}$. In biodiesel production using microalgae, DMC was utilized not only as a transesterification reagent, but also as a solvent for bio-oil extraction from biomass, which makes production process simple and cost effective [50-52].

Table 3. Summary of studies using bio-catalysts during DMC-mediated transesterification.

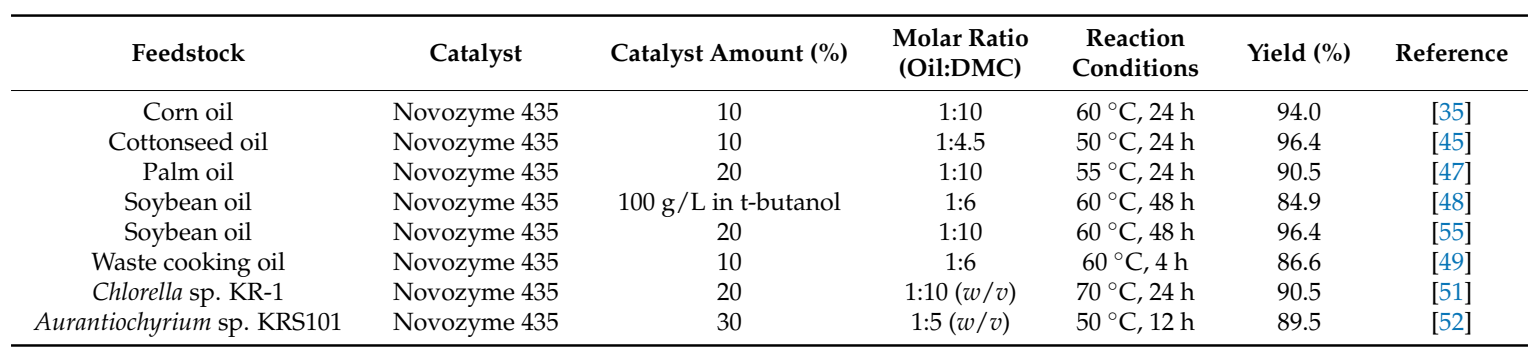




\subsubsection{Fuel Properties of DMC-Based Biodiesel}

The main difference of DMC-based transesterification with the conventional method using methanol is the formation of FAGCs in the methyl ester phase. Fabbri et al. [38] examined the chemical features and physical properties of DMC-based biodiesel as a fuel. Based on fuel property, the presence of FAGCs in DMC-based biodiesel has a negative effect on flow properties compared to conventional biodiesel (pure FAMEs). DMC-based biodiesel has a higher pour point and viscosity than pure FAMEs because FAGCs are 86 Da larger than FAMEs [38,58]. Nevertheless, DMC-based biodiesel can be used as an additive, and the addition of $20 \%$ DMC-based biodiesel to diesel was adequate for normal fuel performance. When compared to pure FAMEs, the emission levels of PAHs during combustion of FAGCs were not significantly different, although more oxygen atoms are present in FAGCs. Despite the presence of FAGCs in the FAMEs phase, the cetane number was similar to pure FAMEs. The fuel properties of DMC-based biodiesel are summarized in Table 4.

Table 4. Properties of biodiesel synthesized via DMC-mediated transesterification.

\begin{tabular}{|c|c|c|c|c|c|}
\hline & \multirow{2}{*}{ Unit } & \multirow{2}{*}{$\operatorname{ASTM}^{a}$} & \multicolumn{3}{|c|}{ DMC-Based Biodiesel } \\
\hline & & & Reference [38] & Reference [41] & Reference [43] \\
\hline Cetane number & & 47 & 50.1 & & \\
\hline Kinetic viscosity $\left(40^{\circ} \mathrm{C}\right)$ & $\mathrm{mm}^{2} / \mathrm{s}$ & $1.9-6.0$ & 4.1 & 5.2 & 5.6 \\
\hline Density $\left(25^{\circ} \mathrm{C}\right)$ & $\mathrm{kg} / \mathrm{m}^{3}$ & - & 0.88 & 0.89 & 0.885 \\
\hline Flash point & ${ }^{\circ} \mathrm{C}$ & 130 & 160 & 122 & 144 \\
\hline Pour point & ${ }^{\circ} \mathrm{C}$ & -15 to 10 & -3.8 & 3 & \\
\hline Acid number & $\mathrm{mg} \mathrm{KOH} / \mathrm{g}$ & $0.0-0.50$ & $<0.5$ & 0.28 & 0.42 \\
\hline Phosphorus content & $\mathrm{mg} / \mathrm{kg}$ & 0-10 & & & 5 \\
\hline
\end{tabular}

\subsubsection{Techno-Economic and Life Cycle Analysis of Enzymatic Biodiesel Production}

Techno-economic analysis (TEA) is a key indicator for successful industrial scale implementation [59]. Although there is no TEA on enzyme-catalyzed biodiesel production in DMC, its TEA can be deduced from the case study on conventional biodiesel production. Jegannathan et al. [60] evaluated TEA of biodiesel production by using alkali catalyst and biological catalysts (soluble and immobilized enzyme). The ton-based production cost of immobilized lipase process was expected to be $206.96 \%$ higher than alkali catalyst process, while $323.9 \%$ lesser than free enzyme process due to expensive enzyme reuse. The lipase cost is expected to be $49.7 \%$ of total production cost. Therefore, reuse of immobilized lipase had a significant effect on biodiesel production. For example, when lipase price are $1500,1000,750,200$, and $100 \$ / \mathrm{kg}$, respectively, the immobilized lipase needs to be reused for more than 320, 210, 160, 50, and 20 batch reactions without significant loss of catalytic activity [61]. Sotoft et al. [62] also investigated TEA of enzymatic biodiesel production. The estimated biodiesel price was $0.73-1.79 € / \mathrm{kg}$ based on enzyme price of $762.71 € / \mathrm{kg}$ and $0.05-0.75 € / \mathrm{kg}$ with enzyme price of $7.63 € / \mathrm{kg}$. In the case of DMC-based biodiesel production, not only production of biodiesel but also co-production of value-added glycerol carbonate derivatives needs to be considered due to high cost of DMC.

Life cycle analysis (LCA) is a valuable tool for assessment of product's net environmental impact. Harding et al. [63] conducted a LCA of both inorganic and enzyme catalysis for biodiesel production. The LCA result showed that the enzymatic catalysis showed less environmental impact when compared to inorganic catalysis. All of the LCA impacts (fresh water aquatic toxicity, human toxicity, terrestrial ecotoxicity, ozone layer depletion, global warming, acidification, and photochemical oxidation) were expected to be low in the enzyme catalysis. Jegannathan et al. [64] studied the LCA of biodiesel production using alkali and enzyme (soluble and immobilized) catalysts. When biodiesel production capacity is $1 \mathrm{Mg}$, the immobilized lipase process has higher environmental impact than sodium hydroxide and soluble enzyme, because multi-step unit operations of lipase immobilization lead to the increase of raw materials and energy. However, as the production capacity increases, the immobilized 
lipase process shows lower environmental impacts compared to other two processes due to benefit of enzyme reuse. Based on the LCA, enzymatic production of biodiesel with DMC would be better than that with methanol in other conventional organic solvent because DMC is considered less toxic to human and the environment.

\subsection{DMC-Mediated Process for Chemicals Production}

DMC has many applications, such as fuel additives and chemical synthesis reagent [17]. In organic synthesis, DMC is used as a chemical intermediate (carbonylating or methylating reagent) and it can replace conventional reagents such as halohydrocarbon $\left(\mathrm{CH}_{3} \mathrm{X}, \mathrm{X}=\mathrm{I}, \mathrm{Br}, \mathrm{Cl}\right)$, dimethyl sulfate, and phosgene [16,65].

\subsubsection{Chemical Process for DMC-Based Chemicals Production}

Brønsted and Lewis acids were used in DMC-mediated carboxymethylation and methylation with various alcohols and phenols [66]. Deshmukh et al. [67] reported that the use of Brønsted and Lewis acidic ionic liquids enhanced the yield of diphenyl carbonate (DPC) synthesis. DPC, one of the most important intermediates for producing various organic and polymeric materials, was produced by a two-step process involving transesterification and the disproportionation reactions $[17,66]$. The synthesis of five- and six-membered heterocycles from 1,4-, 1,5-diols or 1,4-aminoalcohols with DMC has been developed with a nitrogen bicyclic base. $\mathrm{N}$ - and O-based heterocycles are used as antimicrobial, antioxidant, antimitotic, antiangiogenic, and neuritogenic agents, due to their biological activity [68]. Five- and six-membered carbonates were produced using carbonate phosphonium salts as a catalyst for the transesterification of DMC with diols [69]. Pyo et al. [70] developed the synthetic methods of fiveand six-membered cyclic carbonates from various mono-alcohols in the presence of DMC and molecular sieves without any additional solvent or catalyst. These methods could provide an alternative route for the phosgene-free synthesis of polyurethane and polycarbonates $[67,70]$. Aliphatic polycarbonates were synthesized by DMC and aliphatic diols-based condensation polymerization. Various catalysts, such as Sn compounds, calcined $\mathrm{MgAl}$ hydrotalcites, $\mathrm{Ca}$, a TiO${ }_{2} / \mathrm{SiO}_{2}$ complex system, and sodium alkoxide, have been used in the condensation polymerization of various diols with DMC to produce aliphatic polycarbonates [71-75]. Aliphatic polycarbonates are attractive materials due to their favorable biodegradability, biocompatibility, and non-toxic characteristics [74,75]. López-Garzón et al. [76] developed a green upgrading process for dimethyl succinate production by using DMC as a solvent and an alkylating agent catalyzed by a strong anion exchange resin.

Most starting materials that react with DMC for chemical intermediate production have been petroleum-derived chemicals. Recently, green chemicals derived from biomass have drawn increasing interest. In particular, glycerol carbonate as an environmentally-benign chemical, is an important value-added product due to its versatile applications, such as ingredients for cosmetics and pharmaceuticals, electrolyte for Li-ion batteries, and monomer of plastics [17,77]. The transesterification of glycerol in DMC is a preferred method because it is conducted at mild conditions [17]. As previously mentioned, glycerol is a byproduct in the biodiesel industry. However, biodiesel-derived glycerol (bio-glycerol) cannot satisfy purity and cost requirement [13]. For efficient and economical utilization of bio-glycerol, it needs to be converted to value-added chemicals, such as glycerol carbonate [78-81]. Transesterification of glycerol with DMC is thermodynamically favorable based on the equilibrium constant [80]. The effect of various acid and basic homogeneous and heterogeneous catalysts on the synthesis of glycerol carbonate via transesterification has been studied by Ochoa-Gómez et al. [78], and high yield ( $>95 \%$ ) of glycerol carbonate was obtained by using $\mathrm{CaO}$ as a catalyst. The activity of the $\mathrm{CaO}$ catalyst dramatically increased by the calcination of $\mathrm{CaO}$ due to calcium hydroxide removal from its surface. Among the heterogeneous catalysts, alkali metal oxide, or mixed oxide catalysts have been widely used for glycerol carbonate formation [81]. 


\subsubsection{Enzymatic Process for DMC-Based Chemicals Production}

Recently, biotechnological processes using immobilized lipase for DMC-based chemical production have been accomplished. Enzymatic-catalyzed reactions can proceed with high selectivity under mild conditions [82]. Six-membered cyclic carbonates, as environmentally benign monomers for polyurethanes and polycarbonates, can be synthesized from DMC with trimethylopropane (TMP) or diols using immobilized Candida antarctica lipase (Novozyme 435) [83-86]. Six-membered cyclic trimethylene carbonate was synthesized from 1,3-diols and DMC with a low yield (53\%) in a solvent system of acetonitrile and toluene $(4: 1, v / v)$ using lipase [83]. Recently, Bornadel et al. [86] developed a solvent-free synthesis of six-membered carbonate using lipase in a flow reactor. A high conversion $(81.6 \%)$ was obtained in the solvent-free system.

For ecofriendly synthesis of glycerol carbonate, lipases from C. antrartica and Aspergillus niger have been employed as a biocatalyst [87-90]. Lipase-catalyzed production of glycerol carbonate had a high yield ( 99\%) from glycerol and DMC using Novozyme 435 in the presence of tetrahydrofuran (THF) solvent [87]. However, THF is toxic, thus a solvent-free system was proposed to solve the toxicity problem. Lee et al. [88] used glycerol-coated silica gel as the substrate instead of free glycerol due to poor solubility of glycerol in hydrophobic DMC, and achieved a high yield $(90 \%)$ of glycerol carbonate without solvent. Glycerol carbonate synthesis using A. niger lipase exhibited only 25-60\% yield [89,90]. From these results, C. antarctia lipase has higher catalytic activity than A. niger lipase for glycerol carbonate synthesis from glycerol and DMC. In addition, glycerol carbonate can be obtained as a value-added byproduct by enzymatic transesterification (biodiesel production process) between renewable bio-oil and DMC. Glycerol carbonate and biodiesel were obtained with a conversion of $92 \%$ and $84.9 \%$, respectively, by transesterification using Novozyme 435 with tert-butanol as a solvent [48]. Min et al. [35] reported that the co-production of glycerol carbonate and biodiesel were produced with conversions of $62.5 \%$ and $94 \%$, respectively, from corn oil and DMC via the Novozyme 435-catalyzed transesterification without any solvent. For in-situ lipase-catalyzed transesterification in one-pot batch reaction, Jo et al. [51] obtained $16.73 \mathrm{mg}$ of glycerol carbonate/g biomass from microalgae, Chlorella sp. KR-1, containing $40.9 \%(w / w)$ lipid under the optimal condition. Table 5 summarizes DMC-mediated production of various chemicals.

Table 5. Various applications of DMC-based chemicals.

\begin{tabular}{lll}
\hline \multicolumn{1}{c}{ Product } & \multicolumn{1}{c}{ Reaction (with Reference) } & \multicolumn{1}{c}{ Usage } \\
\hline Diphenyl carbonate & $\begin{array}{l}\text { DMC with phenol [17] } \\
\text { DMC with alcohols [66] }\end{array}$ & $\begin{array}{l}\text { Use as a solvent, plasticizer, and chemical intermediate } \\
\text { for various organic and polymeric compounds }\end{array}$ \\
\hline $\begin{array}{l}\text { Five- and } \\
\text { six-membered carbonates }\end{array}$ & $\begin{array}{l}\text { DMC with diols [70] } \\
\text { DMC with trimethylopropane [85] }\end{array}$ & $\begin{array}{l}\text { Use for pharmaceuticals such as antimicrobial, } \\
\text { antioxidant, antimitotic antiangiogenic }\end{array}$ \\
\hline $\begin{array}{l}\text { Five- and } \\
\text { six-membered heterocycles }\end{array}$ & DMC with aminoalcohols [68] & $\begin{array}{l}\text { Use as a chemical intermediate for engineering } \\
\text { thermoplastics, as well as pharmaceutical applications }\end{array}$ \\
\hline Glycerol carbonate & DMC with glycerol [78] & $\begin{array}{l}\text { Prominent role as the monomer during plastic synthesis } \\
\text { Use as ingredients for cosmetics and pharmaceuticals } \\
\text { Use as an electrolyte for Li-ion batteries }\end{array}$ \\
\hline DMC with bio-oil (triglycerides) [54] & $\begin{array}{l}\text { Use as solvent and polymer additives, as well as in } \\
\text { coating and painting applications }\end{array}$ \\
\hline
\end{tabular}

\subsection{Assessment of DMC-Mediated Co-Production of Biofuels and Chemicals from Renewable Bio-Oil}

Bio-oil (biomass-derived oil) and DMC can both be produced via the capturing of $\mathrm{CO}_{2}$ $\left(\mathrm{CO}_{2}\right.$ sequestration), thus the simultaneous production of biofuels and chemicals using bio-oil and DMC can effectively reduce the $\mathrm{CO}_{2}$ (Figure 4). The DMC-mediated process for integrated production of biofuels and chemicals provides zero-waste utilization of renewable bio-oil and is expected to have commercial potential due to easy separation and purification of product and byproduct, simple downstream treatment, and the formation of a high-value byproduct instead of low-value glycerol [43]. Rathore et al. [43] evaluated the economic potential of the DMC-mediated process of biofuel and 
chemical production from renewable oil. The gross profit margin was expected to be $22.81 \%$ higher in the DMC-based co-production of biofuels and chemicals due to the high revenue of glycerol carbonate $[43,45,91]$. Recently, the development of transformer insulating oil from bio-oil has been investigated [92]. Transformer insulating oil has a higher price than biodiesel. Thus, the co-production of high value-added transformer insulating oil and glycerol carbonate derivatives using DMC would be potentially applicable for industrial implementation.

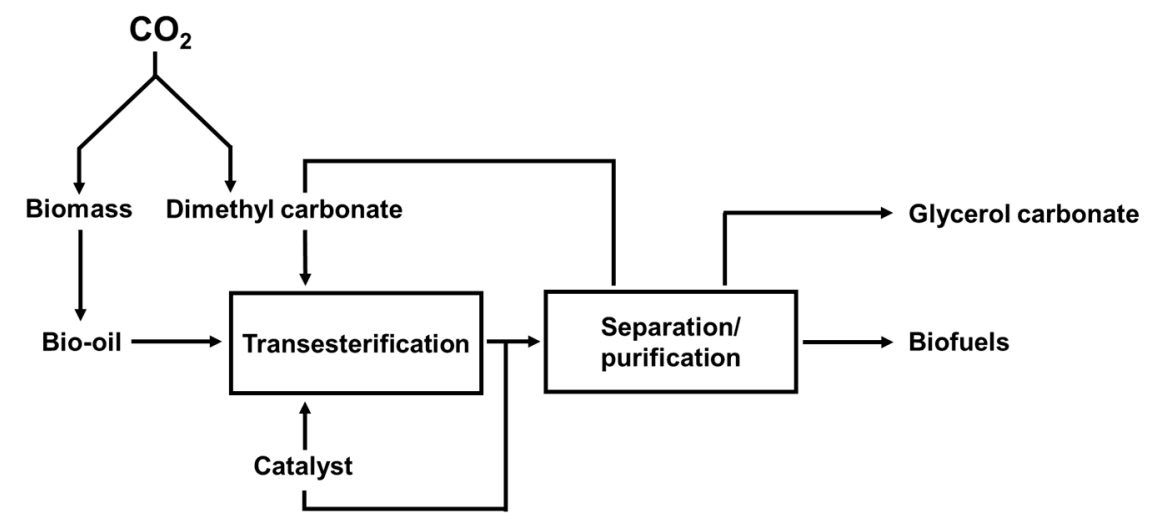

Figure 4. Sustainable and green production of biofuels and glycerol carbonate derivatives.

\section{Concluding Remarks}

DMC is a green chemical and reagent based on its environmentally-benign properties and broad applications. In the DMC-mediated processes for biofuels and chemicals production, there are two types of catalysts used: chemical (acid and base) and enzyme. The chemical catalysis is faster than the enzymatic process. Among the different kinds of chemical catalysis, alkaline catalysis has been widely employed in DMC-mediated biofuels and chemicals production $[34,41,66,69,78]$. The cost of alkaline catalysts, such as metal hydroxides, alkoxides and metal oxides, is comparatively cheaper than enzyme, and high yields have been obtained with chemical catalysis [59]. In contrast, chemical catalysis processes have several drawbacks, such as a high energy requirement, additional downstream process for removing inorganic salts, and large amounts of water for product purification.

Enzyme catalysis is considered an environmentally-benign technology. Lipase has been used as a catalyst in the transesterification for biofuel and chemical production $[46-48,83,88]$. The enzymatic process is conducted at milder conditions compared to the chemical catalysis process, thus requiring less energy consumption. During enzyme catalysis, product separation and purification processes are simple due to high product purity and generation of less wastewater. A disadvantage is that the enzyme-catalyzed product is expensive due to high enzyme cost. Reuse of immobilized lipase can reduce the production cost [52].

DMC-based biodiesel offers some advantages over methanol-based biodiesel with respect to a better lubricating fuel property and oxidation stability [38,43]. In addition, glycerol carbonate as a value-added co-product can lead to a higher gross profit margin of DMC-based biodiesel when compared to conventional biodiesel production. From an economic perspective, the DMC-mediated process for co-production of biofuels and chemicals had shown its potential for its implementation in industry [45]. Additionally, this process may be zero-waste utilization of renewable bio-oil.

At present, the production cost of the DMC-mediated process is $34.7 \%$ greater than the methanol-based process due to the high market price of DMC [43]. Thus, a DMC-mediated process is burdensome for industrial applications in terms of price competitiveness. Commercial production of DMC from carbon dioxide with more competitive price will be one of the key success factors for industrial implementation of DMC-mediated production of biofuels and chemicals in the near future. 
Acknowledgments: This research was supported by Basic Science Research Program through the National Research Foundation of Korea (NRF) funded by the Ministry of Science, ICT and Future Planning (NRF-2017R1A2B4007648). This research was also supported by the C1 Gas Refinery Program through the National Research Foundation of Korea (NRF) funded by the Ministry of Science, ICT \& Future Planning (2015M3D3A1A01064882).

Author Contributions: Keon Hee Kim prepared a draft of the manuscript. Eun Yeol Lee coordinated the study and finalized the manuscript. All authors read and approved the manuscript.

Conflicts of Interest: The authors declare no conflicts of interest.

\section{References}

1. Suganya, T.; Varman, M.; Masjuki, H.H.; Renganathan, S. Macroalgae and microalgae as a potential source for commercial applications along with biofuels production: A biorefinery approach. Renew. Sustain. Energy Rev. 2016, 55, 909-941. [CrossRef]

2. Cherubini, F. The biorefinery concept: Using biomass instead of oil for producing energy and chemicals. Energy Convers. Manag. 2010, 51, 1412-1421. [CrossRef]

3. Leung, D.Y.; Wu, X.; Leung, M.K.H. A review on biodiesel production using catalyzed transesterification. Appl. Energy 2010, 87, 1083-1095. [CrossRef]

4. Verma, P.; Sharma, M.P.; Dwivedi, G. Impact of alcohol on biodiesel production and properties. Renew. Sustain. Energy Rev. 2016, 56, 319-333. [CrossRef]

5. Dawodu, F.A.; Ayodele, O.O.; Xin, J.; Zhang, S. Dimethyl carbonate mediated production of biodiesel at different reaction temperatures. Renew. Energy 2014, 68, 581-587. [CrossRef]

6. Rodrigues, R.C.; Volpato, G.; Wada, K.; Ayub, M.A.Z. Enzymatic synthesis of biodiesel from transesterification reactions of vegetable oils and short chain alcohols. J. Am. Oil Chem. Soc. 2008, 85, 925-930. [CrossRef]

7. Abigor, R.D.; Uadia, P.O.; Foglia, T.A.; Haas, M.J.; Jones, K.C.; Okpefa, E.; Obliuzor, J.U.; Bafor, M.E. Lipase-catalysed production of biodiesel fuel from some Nigerian lauric oils. Biochem. Soc. Trans. 2000, 28, 979-981. [CrossRef] [PubMed]

8. Sanli, H.; Canakci, M. Effects of different alcohol and catalyst usage on biodiesel production from different vegetable oils. Energy Fuels 2008, 22, 2713-2719. [CrossRef]

9. Johnson, D.T.; Taconi, K.A. The glycerin glut: Options for the value-added conversion of crude glycerol resulting from biodiesel production. Environ. Prog. Sustain. Energy 2007, 26, 338-348. [CrossRef]

10. Nanda, M.R.; Yuan, Z.; Qin, W.; Poirier, M.A.; Chunbao, X. Purification of crude glycerol using acidification: Effects of acid types and product characterization. Austin J. Chem. Eng. 2014, 1, 1-7.

11. Yang, F.; Hanna, M.A.; Sun, R. Value-added uses for crude glycerol-A byproduct of biodiesel production. Biotechnol. Biofuels 2012, 5, 13. [CrossRef] [PubMed]

12. Glycerol Market by Source (Biodiesel, Fatty Acids, Fatty Alcohols), by Application (Personal Care, Alkyd Resins, Polyether Polyols), Downstream Opportunities (Propylene Glycol, Epichlorohydrin, 1,3-Propanediol) and Segment Forecasts to 2020. Available online: http://www.grandviewresearch.com/press-release/ global-glycerol-market (accessed on 7 August 2017).

13. Vivek, N.; Sindhu, R.; Madhavan, A.; Anju, A.J.; Castro, E.; Faraco, V.; Pandey, A.; Binod, P. Recent advances in the production of value added chemicals and lipids utilizing biodiesel industry generated crude glycerol as a substrate-Metabolic aspects, challenges and possibilities: An overview. Bioresour. Technol. 2017, 239, 507-517. [CrossRef] [PubMed]

14. Patil, P.D.; Reddy, H.; Muppaneni, T.; Deng, S. Biodiesel fuel production from algal lipids using supercritical methyl acetate (glycerin-free) technology. Fuel 2017, 195, 201-207. [CrossRef]

15. Calero, J.; Luna, D.; Sancho, E.D.; Luna, C.; Bautista, F.M.; Romero, A.A.; Posadillo, A.; Berbel, J.; Verdugo-Escamilla, C. An overview on glycerol-free processes for the production of renewable liquid biofuels, applicable in diesel engines. Renew. Sustain. Energy Rev. 2015, 42, 1437-1452. [CrossRef]

16. Delledonne, D.; Rivetti, F.; Romano, U. Developments in the production and application of dimethylcarbonate. Appl. Catal. A Gen. 2001, 221, 241-251. [CrossRef]

17. Huang, S.; Yan, B.; Wang, S.; Ma, X. Recent advances in dialkyl carbonates synthesis and applications. Chem. Soc. Rev. 2015, 44, 3079-3116. [CrossRef] [PubMed] 
18. Pyo, S.H.; Park, J.H.; Chang, T.S.; Hatti-Kaul, R. Dimethyl carbonate as a Green Chemical. Curr. Opin. Green Sustain. Chem. 2017, 5, 61-66. [CrossRef]

19. Kongpanna, P.; Pavarajarn, V.; Gani, R.; Assabumrungrat, S. Techno-economic evaluation of different $\mathrm{CO}_{2}$-based processes for dimethyl carbonate production. Chem. Eng. Res. Des. 2015, 93, 496-510. [CrossRef]

20. Tundo, P.; Selva, M. The chemistry of dimethyl carbonate. Acc. Chem. Res. 2002, 35, 706-716. [CrossRef] [PubMed]

21. Ono, Y. Catalysis in the production and reactions of dimethyl carbonate, an environmentally benign building block. Appl. Catal. A Gen. 1997, 155, 133-166. [CrossRef]

22. Aricò, F.; Tundo, P. Dimethyl carbonate: A modern green reagent and solvent. Russ. Chem. Rev. 2010, 79, 479-489. [CrossRef]

23. Bhanage, B.M.; Fujita, S.I.; Ikushima, Y.; Arai, M. Synthesis of dimethyl carbonate and glycols from carbon dioxide, epoxides, and methanol using heterogeneous basic metal oxide catalysts with high activity and selectivity. Appl. Catal. A Gen. 2001, 219, 259-266. [CrossRef]

24. Kricsfalussy, Z.; Steude, H.; Waldmann, H.; Hallenberger, K.; Wagner, W.; Traenckner, H.J. Process for Preparing Dimethyl Carbonate. U.S. Patent 5,523,452, 4 June 1996.

25. Han, M.S.; Lee, B.G.; Suh, I.; Kim, H.S.; Ahn, B.S.; Hong, S.I. Synthesis of dimethyl carbonate by vapor phase oxidative carbonylation of methanol over Cu-based catalysts. J. Mol. Catal. A Chem. 2001, 170, 225-234. [CrossRef]

26. Itoh, H.; Watanabe, Y.; Mori, K.; Umino, H. Synthesis of dimethyl carbonate by vapor phase oxidative carbonylation of methanol. Green Chem. 2003, 5, 558-562. [CrossRef]

27. Sato, Y.; Kagotani, M.; Souma, Y. A new type of supportbipyridine containing aromatic polyamide' to $\mathrm{CuCl}_{2}$ for synthesis of dimethyl carbonate (DMC) by oxidative carbonylation of methanol. J. Mol. Catal. A Chem. 2000, 151, 79-85. [CrossRef]

28. Yu, K.M.K.; Curcic, I.; Gabriel, J.; Tsang, S.C.E. Recent advances in $\mathrm{CO}_{2}$ capture and utilization. ChemSusChem 2008, 1, 893-899. [CrossRef] [PubMed]

29. Zhao, T.; Han, Y.; Sun, Y. Novel reaction route for dimethyl carbonate synthesis from $\mathrm{CO}_{2}$ and methanol. Fuel Process. Technol. 2000, 62, 187-194. [CrossRef]

30. Guo, X.C.; Qin, Z.F.; Wang, G.F.; Wang, J.G. Critical temperatures and pressures of reacting mixture in synthesis of dimethyl carbonate with methanol and carbon dioxide. Chin. Chem. Lett. 2008, 19, 249-252. [CrossRef]

31. Jiang, C.; Guo, Y.; Wang, C.; Hu, C.; Wu, Y.; Wang, E. Synthesis of dimethyl carbonate from methanol and carbon dioxide in the presence of polyoxometalates under mild conditions. Appl. Catal. A Gen. 2003, 256, 203-212. [CrossRef]

32. Peng, W.; Zhao, N.; Xiao, F.; Wei, W.; Sun, Y. Recent progress in phosgene-free methods for synthesis of dimethyl carbonate. Pure Appl. Chem. 2011, 84, 603-620. [CrossRef]

33. Bharathiraja, B.; Chakravarthy, M.; Kumar, R.R.; Yuvaraj, D.; Jayamuthunagai, J.; Kumar, R.P.; Palani, S. Biodiesel production using chemical and biological methods-A review of process, catalyst, acyl acceptor, source and process variables. Renew. Sustain. Energy Rev. 2014, 38, 368-382. [CrossRef]

34. Zhang, L.; Sheng, B.; Xin, Z.; Liu, Q.; Sun, S. Kinetics of transesterification of palm oil and dimethyl carbonate for biodiesel production at the catalysis of heterogeneous base catalyst. Bioresour. Technol. 2010, 101, 8144-8150. [CrossRef] [PubMed]

35. Min, J.Y.; Lee, E.Y. Lipase-catalyzed simultaneous biosynthesis of biodiesel and glycerol carbonate from corn oil in dimethyl carbonate. Biotechnol. Lett. 2011, 33, 1789-1796. [CrossRef] [PubMed]

36. Pacheco, M.A.; Marshall, C.L. Review of dimethyl carbonate (DMC) manufacture and its characteristics as a fuel additive. Energy Fuels 1997, 11, 2-29. [CrossRef]

37. Su, E.; You, P.; Wei, D. In situ lipase-catalyzed reactive extraction of oilseeds with short-chained dialkyl carbonates for biodiesel production. Bioresour. Technol. 2009, 100, 5813-5817. [CrossRef] [PubMed]

38. Fabbri, D.; Bevoni, V.; Notari, M.; Rivetti, F. Properties of a potential biofuel obtained from soybean oil by transmethylation with dimethyl carbonate. Fuel 2007, 86, 690-697. [CrossRef]

39. Islam, M.R.; Kurle, Y.M.; Gossage, J.L.; Benson, T.J. Kinetics of triazabicyclodecene-catalyzed canola oil conversion to glycerol-free biofuel using dimethyl carbonate. Energy Fuels 2013, 27, 1564-1569. [CrossRef]

40. Kurle, Y.M.; Islam, M.R.; Benson, T.J. Process development and simulation of glycerol-free biofuel from canola oil and dimethyl carbonate. Fuel Process. Technol. 2013, 114, 49-57. [CrossRef] 
41. Panchal, B.M.; Dhoot, S.B.; Deshmukh, S.A.; Sharma, M.R.; Kachole, M.S. Production of DMC-BioD from Pongamia pinnata seed oil using dimethyl carbonate. Fuel 2013, 109, 201-205. [CrossRef]

42. Kai, T.; Mak, G.L.; Wada, S.; Nakazato, T.; Takanashi, H.; Uemura, Y. Production of biodiesel fuel from canola oil with dimethyl carbonate using an active sodium methoxide catalyst prepared by crystallization. Bioresour. Technol. 2014, 163, 360-363. [CrossRef] [PubMed]

43. Rathore, V.; Tyagi, S.; Newalkar, B.; Badoni, R.P. Jatropha and Karanja oil derived DMC—Biodiesel synthesis: A kinetics study. Fuel 2015, 140, 597-608. [CrossRef]

44. Schuchardt, U.; Vargas, R.M.; Gelbard, G. Alkylguanidines as catalysts for the transesterification of rapeseed oil. J. Mol. Catal. A Chem. 1995, 99, 65-70. [CrossRef]

45. Ang, G.T.; Tan, K.T.; Lee, K.T. Recent development and economic analysis of glycerol-free processes via supercritical fluid transesterification for biodiesel production. Renew. Sustain. Energy Rev. 2014, 31, 61-70. [CrossRef]

46. Su, E.Z.; Zhang, M.J.; Zhang, J.G.; Gao, J.F.; Wei, D.Z. Lipase-catalyzed irreversible transesterification of vegetable oils for fatty acid methyl esters production with dimethyl carbonate as the acyl acceptor. Biochem. Eng. J. 2007, 36, 167-173. [CrossRef]

47. Zhang, L.; Sun, S.; Xin, Z.; Sheng, B.; Liu, Q. Synthesis and component confirmation of biodiesel from palm oil and dimethyl carbonate catalyzed by immobilized-lipase in solvent-free system. Fuel 2010, 89, 3960-3965. [CrossRef]

48. Seong, P.J.; Jeon, B.W.; Lee, M.; Cho, D.H.; Kim, D.K.; Jung, K.S.; Kim, S.W.; Han, S.O.; Kim, Y.H.; Park, C. Enzymatic coproduction of biodiesel and glycerol carbonate from soybean oil and dimethyl carbonate. Enzyme Microb. Technol. 2011, 48, 505-509. [CrossRef] [PubMed]

49. Gharat, N.; Rathod, V.K. Ultrasound assisted enzyme catalyzed transesterification of waste cooking oil with dimethyl carbonate. Ultrason. Sonochem. 2013, 20, 900-905. [CrossRef] [PubMed]

50. Lee, O.K.; Kim, Y.H.; Na, J.G.; Oh, Y.K.; Lee, E.Y. Highly efficient extraction and lipase-catalyzed transesterification of triglycerides from Chlorella sp. KR-1 for production of biodiesel. Bioresour. Technol. 2013, 147, 240-245. [CrossRef] [PubMed]

51. Jo, Y.J.; Lee, O.K.; Lee, E.Y. Dimethyl carbonate-mediated lipid extraction and lipase-catalyzed in situ transesterification for simultaneous preparation of fatty acid methyl esters and glycerol carbonate from Chlorella sp. KR-1 biomass. Bioresour. Technol. 2014, 158, 105-110. [CrossRef] [PubMed]

52. Kim, K.H.; Lee, O.K.; Kim, C.H.; Seo, J.W.; Oh, B.R.; Lee, E.Y. Lipase-catalyzed in-situ biosynthesis of glycerol-free biodiesel from heterotrophic microalgae, Aurantiochytrium sp. KRS101 biomass. Bioresour. Technol. 2016, 211, 472-477. [CrossRef] [PubMed]

53. Marx, S. Glycerol-free biodiesel production through transesterification: A review. Fuel Process. Technol. 2016, 151, 139-147. [CrossRef]

54. Del Pilar Rodriguez, M.; Brzezinski, R.; Faucheux, N.; Heitz, M. Enzymatic transesterification of lipids from microalgae into biodiesel: A review. AIMS Energy 2016, 4, 817-855. [CrossRef]

55. Go, A.R.; Lee, Y.; Kim, Y.H.; Park, S.; Choi, J.; Lee, J.; Han, O.S.; Kim, S.W.; Park, C. Enzymatic coproduction of biodiesel and glycerol carbonate from soybean oil in solvent-free system. Enzyme Microb. Technol. 2013, 53, 154-158. [CrossRef] [PubMed]

56. Demirbas, A.; Demirbas, M.F. Importance of algae oil as a source of biodiesel. Energy Convers. Manag. 2011, 52, 163-170. [CrossRef]

57. Lee, O.K.; Seong, D.H.; Lee, C.G.; Lee, E.Y. Sustainable production of liquid biofuels from renewable microalgae biomass. J. Ind. Eng. Chem. 2015, 29, 24-31. [CrossRef]

58. Lapuerta, M.; Rodríguez-Fernández, J.; Estevez, C.; Bayarri, N. Properties of fatty acid glycerol formal ester (FAGE) for use as a component in blends for diesel engines. Biomass Bioenergy 2015, 76, 130-140. [CrossRef]

59. Guldhe, A.; Singh, B.; Mutanda, T.; Permaul, K.; Bux, F. Advances in synthesis of biodiesel via enzyme catalysis: Novel and sustainable approaches. Renew. Sustain. Energy Rev. 2015, 41, 1447-1464. [CrossRef]

60. Jegannathan, K.R.; Eng-Seng, C.; Ravindra, P. Economic assessment of biodiesel production: Comparison of alkali and biocatalyst processes. Renew. Sustain. Energy Rev. 2011, 15, 745-751. [CrossRef]

61. Zhao, X.; Qi, F.; Yuan, C.; Du, W.; Liu, D. Lipase-catalyzed process for biodiesel production: Enzyme immobilization, process simulation and optimization. Renew. Sustain. Energy Rev. 2015, 44, 182-197. [CrossRef] 
62. Sotoft, L.F.; Rong, B.G.; Christensen, K.V.; Norddahl, B. Process simulation and economical evaluation of enzymatic biodiesel production plant. Bioresour. Technol. 2010, 101, 5266-5274. [CrossRef] [PubMed]

63. Harding, K.G.; Dennis, J.S.; Von Blottnitz, H.; Harrison, S.T.L. A life-cycle comparison between inorganic and biological catalysis for the production of biodiesel. J. Clean. Prod. 2008, 16, 1368-1378. [CrossRef]

64. Jegannathan, K.R.; Vanessa, F.W.T.; Ravindra, P. Life cycle assessment of biodiesel production using alkali, soluble and immobilized enzyme catalyst processes. Biomass Bioenergy 2011, 35, 4221-4229.

65. Selva, M. Green approaches to highly selective processes: Reactions of dimethyl carbonate over both zeolites and base catalysts. Pure Appl. Chem. 2007, 79, 1855-1867. [CrossRef]

66. Jin, S.; Hunt, A.J.; Clark, J.H.; McElroy, C.R. Acid-catalysed carboxymethylation, methylation and dehydration of alcohols and phenols with dimethyl carbonate under mild conditions. Green Chem. 2016, 18, 5839-5844. [CrossRef]

67. Deshmukh, K.M.; Qureshi, Z.S.; Dhake, K.P.; Bhanage, B.M. Transesterification of dimethyl carbonate with phenol using Brønsted and Lewis acidic ionic liquids. Catal. Commun. 2010, 12, 207-211. [CrossRef]

68. Aricò, F.; Evaristo, S.; Tundo, P. Synthesis of five-and six-membered heterocycles by dimethyl carbonate with catalytic amounts of nitrogen bicyclic bases. Green Chem. 2015, 17, 1176-1185. [CrossRef]

69. Selva, M.; Caretto, A.; Noè, M.; Perosa, A. Carbonate phosphonium salts as catalysts for the transesterification of dialkyl carbonates with diols. The competition between cyclic carbonates and linear dicarbonate products. Org. Biomol. Chem. 2014, 12, 4143-4155. [CrossRef] [PubMed]

70. Pyo, S.H.; Hatti-Kaul, R. Chlorine-Free Synthesis of Organic Alkyl Carbonates and Five-and Six-Membered Cyclic Carbonates. Adv. Synth. Catal. 2016, 358, 834-839. [CrossRef]

71. Pokharkar, V.; Sivaram, S. Poly (alkylene carbonate) s by the carbonate interchange reaction of aliphatic diols with dimethyl carbonate: Synthesis and characterization. Polymer 1995, 6, 4851-4854. [CrossRef]

72. Feng, Y.X.; Yin, N.; Li, Q.F.; Wang, J.W.; Kang, M.Q.; Wang, X.K. Environmentally Benign Route for the Synthesis of Polycarbonate Diols (PCDLs)—Calcined MgAl Hydrotalcites as Heterogeneous Catalysts. Ind. Eng. Chem. Res. 2008, 47, 2140-2145. [CrossRef]

73. Foy, E.; Farrell, J.B.; Higginbotham, C.L. Synthesis of linear aliphatic polycarbonate macroglycols using dimethylcarbonate. J. Appl. Polym. Sci. 2009, 111, 217-227. [CrossRef]

74. Zhu, W.; Huang, X.; Li, C.; Xiao, Y.; Zhang, D.; Guan, G. High-molecular-weight aliphatic polycarbonates by melt polycondensation of dimethyl carbonate and aliphatic diols: Synthesis and characterization. Polym. Int. 2011, 60, 1060-1067. [CrossRef]

75. Park, J.H.; Jeon, J.Y.; Lee, J.J.; Jang, Y.; Varghese, J.K.; Lee, B.Y. Preparation of high-molecular-weight aliphatic polycarbonates by condensation polymerization of diols and dimethyl carbonate. Macromolecules 2013, 46, 3301-3308. [CrossRef]

76. López-Garzón, C.S.; van der Wielen, L.A.; Straathof, A.J. Green upgrading of succinate using dimethyl carbonate for a better integration with fermentative production. Chem. Eng. J. 2014, 235, 52-60. [CrossRef]

77. Álvarez, M.G.; Chimentão, R.J.; Figueras, F.; Medina, F. Tunable basic and textural properties of hydrotalcite derived materials for transesterification of glycerol. Appl. Clay Sci. 2012, 58, 16-24. [CrossRef]

78. Ochoa-Gómez, J.R.; Gómez-Jiménez-Aberasturi, O.; Maestro-Madurga, B.; Pesquera-Rodríguez, A.; Ramírez-López, C.; Lorenzo-Ibarreta, L.; Torrecilla-Soria, J.; Villarán-Velasco, M.C. Synthesis of glycerol carbonate from glycerol and dimethyl carbonate by transesterification: Catalyst screening and reaction optimization. Appl. Catal. A Gen. 2009, 366, 315-324. [CrossRef]

79. Li, J.; Wang, T. Coupling reaction and azeotropic distillation for the synthesis of glycerol carbonate from glycerol and dimethyl carbonate. Chem. Eng. Process. 2010, 49, 530-535. [CrossRef]

80. Li, J.; Wang, T. Chemical equilibrium of glycerol carbonate synthesis from glycerol. J. Chem. Thermodyn. 2011, 43, 731-736. [CrossRef]

81. Algoufi, Y.T.; Hameed, B.H. Synthesis of glycerol carbonate by transesterification of glycerol with dimethyl carbonate over K-zeolite derived from coal fly ash. Fuel Process. Technol. 2014, 126, 5-11. [CrossRef]

82. Jiang, Z.; Liu, C.; Xie, W.; Gross, R.A. Controlled lipase-catalyzed synthesis of poly (hexamethylene carbonate). Macromolecules 2007, 40, 7934-7943. [CrossRef]

83. Tasaki, H.; Toshima, K.; Matsumura, S. Enzymatic synthesis and polymerization of cyclic trimethylene carbonate monomer with/without methyl substituent. Macromol. Biosci. 2003, 3, 436-441. [CrossRef]

84. Pyo, S.H.; Persson, P.; Lundmark, S.; Hatti-Kaul, R. Solvent-free lipase-mediated synthesis of six-membered cyclic carbonates from trimethylolpropane and dialkyl carbonates. Green Chem. 2011, 13, 976-982. [CrossRef] 
85. Pyo, S.H.; Hatti-Kaul, R. Selective, Green Synthesis of Six-Membered Cyclic Carbonates by Lipase-Catalyzed Chemospecific Transesterification of Diols with Dimethyl Carbonate. Adv. Synth. Catal. 2012, 354, 797-802. [CrossRef]

86. Bornadel, A.; Ismail, M.; Sayed, M.; Hatti-Kaul, R.; Pyo, S.H. Six-membered cyclic carbonates from trimethylolpropane: Lipase-mediated synthesis in a flow reactor and in silico evaluation of the reaction. Biotechnol. Prog. 2017, 33, 375-382. [CrossRef] [PubMed]

87. Kim, S.C.; Kim, Y.H.; Lee, H.; Song, B.K. Lipase-catalyzed synthesis of glycerol carbonate from renewable glycerol and dimethyl carbonate through transesterification. J. Mol. Catal. B Enzym. 2007, 49, 75-78. [CrossRef]

88. Lee, K.H.; Park, C.H.; Lee, E.Y. Biosynthesis of glycerol carbonate from glycerol by lipase in dimethyl carbonate as the solvent. Bioprocess Biosyst. Eng. 2010, 33, 1059-1065. [CrossRef] [PubMed]

89. Tudorache, M.; Protesescu, L.; Coman, S.; Parvulescu, V.I. Efficient bio-conversion of glycerol to glycerol carbonate catalyzed by lipase extracted from Aspergillus niger. Green Chem. 2012, 14, 478-482. [CrossRef]

90. Tudorache, M.; Negoi, A.; Tudora, B.; Parvulescu, V.I. Environmental-friendly strategy for biocatalytic conversion of waste glycerol to glycerol carbonate. Appl. Catal. B 2014, 146, 274-278. [CrossRef]

91. Zhu, L. Biorefinery as a promising approach to promote microalgae industry: An innovative framework. Renew. Sustain. Energy Rev. 2015, 41, 1376-1384. [CrossRef]

92. Rafiq, M.; Lv, Y.Z.; Zhou, Y.; Ma, K.B.; Wang, W.; Li, C.R.; Wang, Q. Use of vegetable oils as transformer oils-A review. Renew. Sustain. Energy Rev. 2015, 52, 308-324. [CrossRef]

(C) 2017 by the authors. Licensee MDPI, Basel, Switzerland. This article is an open access article distributed under the terms and conditions of the Creative Commons Attribution (CC BY) license (http://creativecommons.org/licenses/by/4.0/). 